the photograph and coloured geological map included in the guide will give a clear impression of its features.

Signor Luigi de Marchi has published, through the Reale Istituto Veneto (1905), a folio memoir on "L'Idrografia dei Colli Euganei," in which much attention is paid to the question of the change of slope in the bed of a stream according to the grouping of the rocks successively encountered by it. An interesting result (p. 46), borne out by other evidence, is that the trachytic masses round the central tuff-cone of the Venda are found, not to lie, as Suess and Reyer have supposed, upon fragmental deposits as relics of great viscid lava-flows, but represent independent volcanic necks rising through a mantle of softer rocks. Observations are added on the limitation of human activity on the mountain-sides by the progress of denudation.

In the Verhandlungen der $k . k$ geologischen Reichsanstalt for $1905 \mathrm{Dr}$. Kerner (p. 127) gives the results of five weeks' study of the Neogene deposits of Sinj, in central Dalmatia, and (p. 593) describes the fossil plants collected. Dr. Franz Baron Nopesa (Jahrbuch, ibid., 1905, p. 85) leads us farther south, having been able, with the aid of the Turkish authorities, to study the geology of Albania. He gives a pleasant account of the country that should attract other travellers. Not every. geologist can be an artist, and we feel that some of the drawings, made by the author from his photographs, might have been well entrusted to other hands. The author believes that the so-called Flysch of Albania and Bosnia is at latest of Middle Mesozoic age, and has nothing to do with the Flysch of the Dalmatian coast-ranges and of the Wiener Wald. Baron Nopcsa writes very modestly of his results; but he has clearly felt the fascination of working, within the bounds of Europe, in a virgin field. The bibliography provided should help explorers of various tastes.

In the same Jahrbuch (p. 349) Mr. W. A. Humphrey, " aus York, England," reports on the ore-deposits of the Stangalp. His remarks on the so-called Urgebirge of Styria and Carinthia are of general interest, since he finds that the gneiss and the mica-schist vary inversely in importance on the margin of a mass of alpine granite. This granite has affected even the interstitial material of the Carboniferous conglomerate, while tourmaline has been formed among the sediments far beyond the zone where they are injected with actual granite-veins. Mr. Humphrey therefore (pp. 363-5) regards the whole sedimentary and schistose mass as a continuous series, which became highly metamorphosed in its lower portions. Here we once more recognise the change of opinion, forced upon field-observers in very diverse areas, with regard to the alleged antiquity of schists in mountain-cores.

Dr. Ampferer's extensive paper (ibid., pp. 45I-562) on the Wettersteingebirge, among his favourite limestone Alps, introduces questions of torsional movement combined with thrust-planes. In Spelunca, Nos. 42 and 43 (1905), M. Martel deals with the subterranean aspects of limestones, in continuing his immensely valuable abstracts of recent papers upon caves. These two numbers, which are issued as one, cover the whole area outside France, and even contain references to Kerguelen Island and the Fijis.

G. A. J. C.

\section{METEOROLOGICAL REPORTS.}

I $N$ the Journal of the Meteorological Society of Japan for February, Mr. H. Mukasa gives a summary of the temperature conditions at Chemulpo (Korea) for the years $1893^{-1903}$, from four observations daily. The mean of the daily maxima in summer is $80^{\circ} \cdot 6$, in winter $37^{\circ} \cdot 9$, and the mean of the minima $67^{\circ} \cdot 3$ and $22^{\circ} .8$ respectively. The absolute maximum was $99^{\circ} \cdot 5$, in August, I90r, and the minimum $-1^{\circ} \cdot 3$, in February, 1895 ; the greatest daily range, $40^{\circ} \cdot 3$, also occurred in the latter month. The Journal for April contains an interesting contribution on the management of the wet-bulb thermometer, by $\mathrm{Mr}$. $\mathrm{T}$. Okada. It was pointed out by Dr. Edelmann in the Metcorologische Zeitschrift for 1896 , p. 334 , that the kind of covering used for conveying moisture to the bulb had considerable influence on the readings of the thermometer.

NO. I9I7, VOL. 74]
Prof. Tanakadate has recently found that a Japanese paper called "Yoshinogami," made from fibres of a species of mulberry tree, was most suited for a cover for the wetbulb both for temperatures above and below freezing point, and, being quite easy in manipulation, can be changed even daily without the slightest trouble. Mr. Okada's experiments show that the bulb covered with paper is more sensitive than one with the usual muslin covering, and that in frosty weather its indications give the humidity more in accordance with that shown by the hair-hygrometer. The paper is said to be suitable for all climates.

The Proceedings of the Rhodesia Scientific Association (vol. v., part ii.) contains monthly and annual means of meteorological observations made at Bulawayo (altitude about 4469 feet) from 1897 to 1904 by the Jesuit Fathers Barthélemy and Nicot. As the observations mostly refer to $9 \mathrm{~h}$. a.m., the results can only be taken as approximate, but the discussion by the Rev. E. Goetz, S.J., is nevertheless very useful. The absolute highest reading of the barometer was $26 \cdot 17 \mathrm{I}$ inches (in July), and the lowest 25.397 inches (in January); the daily range rarely exceeds $\mathrm{O} \cdot \mathrm{I}$ inch. The temperature shows one minimum, in June, and two maxima, in October and January; the means of maximum and minimum readings for these months are $57^{\circ} \cdot 5,73^{\circ} \cdot 7$, and $72^{\circ} \cdot 6$ respectively. The absolute extremes were $105^{\circ}$ in November and $33^{\circ}$ in June (in June, 1905 , not included in the tables, the temperature in the screen fell to $30^{\circ}$ ). The rainfall has two maxima, one in the beginning of December, followed by a serious break, and a second in the middle of January. Mr. Goetz states that this break in the rainfall is a very disastrous feature of the climate, as the crops are either destroyed or stunted by the burning sun. The annual rainfall averages 22.2 inches, and the rainy days seventy-four. Very little rain falls between May and September; it is very heavy during thunderstorms, and for some minutes falls at the rate of from 2 inches to 6 inches an hour.

Sir Charles Todd has recently published the meteorological observations made at the Adelaide Observatory and other places in South Australia during 1902 and 1903. He states that the year 1902 must be classed as one of the driest on record, particularly during the winter season (April to October). The returns for 1903 show a general improvement; on the average, the agricultural areas had about 3 inches above the normal rainfall. A marked feature of this year was that during every month, except September to November, the mean temperature at Adelaide was below the average; the lowest air temperature on record at that place, $3^{\circ} \cdot 2$, was observed on July II. The highest shade-temperature was $105^{\circ} .6$, in February.

The report of the Government astronomer of Natal for the year 1905 has been condensed; in the case of the subsidiary stations, meteorological summaries only are given, and the daily results are only published for the observatory at Durban. The rainfall for the year at that place was 44.95 inches, which is 5.6 inches above the average of the previous twenty-one years. This result was owing to one of the most remarkable hurricanes that have occurred in Natal during the last thirty years, which swept over the entire colony with extraordinary severity on May $3 x$ and June $x$. The rainfall on these two days amounted to nearly II inches at Durban and to 17 inches at Umzinto. The mean temperature of the year was exceptionally low; the mean of the maxima was $78^{\circ} \cdot 1$ and of the minima $6 \mathrm{I}^{\circ} \cdot 4$, and the extremes were $90^{\circ} \cdot 7$ and $45^{\circ} \cdot 4$ respectively. The only year of lower mean temperature was 1887 .

Captain H. G. Lyons, director-general of the Survey Department, Egypt, has published his report on the rain of the Nile basin in 1905. The Egyptian and Soudan stations at which rainfall is measured only number thirtyone, but a good many other returns showing the days on which rain fell are received, and are to some extent useful in supplementing the information supplied by the recording stations; observations are also given for neighbouring territories. On the whole, the rainfall is said to have been everywhere deficient; the volume of the Nile flood considered as the volume passing Aswan between July t and October $3 \mathrm{I}$, was only 0.65 of the average for thirty 
four years (1869-1903), making the ninth successive year of low floods. The mean rainfall, and the oscillation of the rain-belt with the apparent motion of the sun, are very clearly shown by coloured maps, drawn for each month.

The report of the Falmouth Observatory committee of the Royal Cornwall Polytechnic Society for the year I905 (one of the principal observatories subsidised by the Meteorological Office) shows that a record reading of the barometer for that part of the British Islands occurred on January 28, viz. 31.097 inches (corrected and reduced to sea-level). The next highest reading at Falmouth during the last thirty years was $30.98 \mathrm{I}$ inches, on January 18 , 1882. Another interesting point is the mean temperature of the sea-surface, taken one mile outside the harbour, viz. $53^{\circ} \cdot 3$, being $2^{\circ} \cdot 3$ above the mean temperature of the air. The mean monthly sea-temperature was only below that of the air in June, July, and August. Much attention is given to magnetic observations, and the instruments are not affected by electric tramways. During a display of aurora borealis on the night of November 15, an easterly movement in the declination took place at $8 \mathrm{~h} .53 \mathrm{~m}$. p.m. which in twelve minutes reduced it about $33^{\prime}$, while in the subsequent twenty minutes the declination increased about $4 \mathrm{I}^{\prime}$, which was $8^{\prime}$ west of its position before the movement occurred.

The Jahrbuch of the Norwegian Meteorological Institute for 1905 contains hourly observations for Christiania, with tri-daily readings and summaries for other stations. The results are given according to the international scheme, as before, the only change being that mid-European time has been introduced (one hour earlier than Greenwich), so that the observations at telegraphic reporting stations, which were previously taken by Christiania time, are now made seventeen minutes earlier than in previous years, while at the ordinary stations the time of taking observations has not been altered. Accompanying the Jahrbuch is part xiv. of the valuable series of climatological tables for Norway, containing the average monthly amount of cloud for the various directions of wind (" cloud windroses"); at most of the stations the averages are for a period of twenty years ( $1876-95)$.

The trigonometrical branch office at Dehra Dun has published a valuable series of daily rainfall observations for each of the thirtysix years r868-1903. The mean annual fall is 84.72 inches, of which 65 per cent. falls in July and August. The maximum yearly amount was 122.47 inches, in 1894, and the minimum 41.69 inches, in 1877. The greatest fall in one day was 12.47 inches, on August 10, 1896. From a summary of the highest and lowest temperatures in the shade, for the same years, we observe that the mean of the annual extremes was $104^{\circ} \cdot 3$, the absolute maximum being $108^{\circ} \cdot 4$, on May 19 , 1892 $\left(108^{\circ} \cdot 3\right.$ on June 5,1890 ), and the minimum $31^{\circ} \cdot 8$, on January 13,1874 , the next lowest being $33^{\circ} \cdot 9$, on February 5,1876 .

\section{COLOURING OF GUEREZA MONKEYS.}

I N vol. ii. of the Proceedings of the Zoological Society of the current year, Mr. Lydekker contributes a paper on colour-evolution in the black or black and white tropical African monkeys of the genus Colobus commonly known as guerezas. Starting with a wholly black monkey, like the West African $C$. satanas, in which, although there is a fringe of long hair round the face, the body is comparatively short-haired and the tail not tufted, the author shows how a gradation can be traced through species like C. palliatus and $C$. sharpei of East Central Africa, in which tufts of long white hair (larger in the second than in the first of the two species named) make their appearance on the sides of the face and shoulders, as well as on the terminal third of the tail, to the Abyssinian C. guereza, in which the white shoulder-tufts extend backwards to

No. I9I7, VoL. 74] form a mantle on each side of the body, and unite on the lower part of the back. The culmination of this type is formed by the white-tailed guereza (C. caudatus) of the Kilimanjaro district, in which the pendent white mantle is still longer, and the tail, which is wholly white except for a small length at the root, is clothed with long pendent hair : the cheek- and throat-tufts, however, have been lost, so that the head is short-haired, with the face and throat white.

The West African white-thighed guereza (C. vellerosus) appears to exhibit a kind of retrograde development in these respects, the body having lost the mantle of long white hair and the tail its white "flag," while the white of the perineal patch has spread on to the hinder and outer sides of the thighs. In this case we find practical reversion to the type of the black guereza, with the exception that the band on the forehead, the sides of the face and throat, the thighs, and almost the whole tail have become white, while the long hair has disappeared from the face. In the opinion of the author the colouring and special develop- 